\title{
Assessment of Plasmodium falciparum histidine rich protein 2 and /3 (pfhrp 2\&/ pfhrp 3) gene deletion or mutation in all Plasmodium falciparum positive blood samples in a tertiary care centre in South India
}

\section{Monika Sivaradjy}

JIPMER: Jawaharlal Institute of Postgraduate Medical Education and Research

\section{Abdoul Hamide}

JIPMER: Jawaharlal Institute of Postgraduate Medical Education and Research

\section{Sriram Krishnamurthy}

JIPMER: Jawaharlal Institute of Postgraduate Medical Education and Research

Vamsi mohan

JIPMER: Jawaharlal Institute of Postgraduate Medical Education and Research

Ferdina Marie Sharmila

JIPMER: Jawaharlal Institute of Postgraduate Medical Education and Research

Nonika Rajkumari ( $\nabla$ nonika.raj@gmail.com )

JIPMER: Jawaharlal Institute of Postgraduate Medical Education and Research

https://orcid.org/0000-0002-4326-3877

\section{Research Article}

Keywords: Pfhrp2, Pfhrp3, Rapid diagnostic card test, Plasmodium falciparum, gene deletion

Posted Date: January 28th, 2022

DOI: https://doi.org/10.21203/rs.3.rs-1212405/v1

License: @ (i) This work is licensed under a Creative Commons Attribution 4.0 International License. Read Full License 


\section{Abstract}

Rapid diagnostic card tests (RDTs) enable timely and appropriate diagnosis of malaria especially in remote areas. Plasmodium falciparum histidine rich protein 2 (PFHRP2) is the most targeted antigen for the detection of Plasmodium falciparum infections by rapid diagnostic card test. Genetic mutations and gene deletions are important emerging factors for false-negative RDTs, which may delay the provision of life-saving treatment for the patients. Hence, we would like to evaluate for the existence of $p f h r p 2 / 3$ gene deleted P.falciparum parasites in our health care setting. This study was conducted for a period of 2 years in a tertiary care centre in South India. Blood samples that are microscopically confirmed as $P$. falciparum but negative by RDT were assessed for the presence of $p f h r p 2, p f h r p 3$, and their flanking genes using conventional PCR. Follow up of the clinical outcomes were also done for these patients. Of the 63 positive samples collected (50/63) 79.4\% were P.vivax and (13/63) 20.6\% were P.falciparum by PCR. Among the 13 P.falciparum positive samples, 4 samples (4/13), (95\% $\mathrm{Cl}-10.36-61.11 \%)$ were found to be RDT negative but microscopically positive.Pfhrp2,pfhrp3 and their flanking genes were amplified for these 4 samples. All 4 samples were found to be negative for both pfhrp2-2 \& pfhrp2-3 exon regions and also varying patterns of flanking gene deletions were also noted. This study provides molecular evidence for the existence of pfhrp2 \& pfhrp3 deleted $P$. falciparum parasites in a tertiary care centre in South India warranting periodic evaluation of pfhrp2 based RDT use. Only pfhrp2/3 RDT based decision on diagnosis of P.falciparum malaria should always be reconsidered especially in remote areas.

Brief running title: Pfhrp2/3 gene deletion

\section{Background}

Malaria is one of the serious arthropod-borne infectious diseases which results in major mortality and morbidity globally. World Health Organization (WHO) Malaria Report 2019 says that an estimated 228 million cases of malaria occurred worldwide in 2018 (World Health Organization,2019). Malaria is endemic in all six WHO regions and the burden is highest in the sub-Saharan African region, where an estimated $90 \%$ of all malaria deaths occur (World Health Organization, 2015). As per world malaria report 2019, India accounts for $3 \%$ of the global malaria burden (World Health Organization, 2019).Rapid diagnostic card tests (RDTs) are one of the most useful tools that assist in the early diagnosis of malaria. Since its introduction, a wide variety of RDTs have been developed for the detection of different antigens likePFHRP $2 / 3$ (Plasmodium falciparum histidine rich protein) andenzymes like lactate dehydrogenase, aldolase. Pfhrp2 is the frequently targeted antigen to detect $P$. falciparum malaria that causes more serious infection with highest mortality (Fontecha $\mathrm{G}$ et al., 2018). The pfhrp2 gene that codes for P.falciparum specific PfHRP2 antigen is located on chromosome 8 and pfhrp3 gene that codes for PfHRP3 antigen (which is the structural analogue of pfhrp2) is on chromosome 13(Fontecha $\mathrm{G}$ et al.,2018 and Nderu D et al., 2019). Spread of the P.falciparum isolates that lacks or fails to express $p f h r p 2 / 3$ genes due to genetic mutation or gene deletion is threatening the reliability of the use of $p f h r p 2 / 3$ based RDTs. Hence, analysing the genetic diversity of $p f h r p 2 / 3$ genes is an essential component in malaria control. This may lead to delay in the provision of lifesaving treatment for individual patients and also simultaneously increase the number of persons capable of infecting mosquitoes and spread the resistance in the community. Deletion of Pfhrp2 and Pfhrp3 is being reported from various places worldwide but such data is very limited in India (Kumar $\mathrm{N}$ et al., 2013). In this pilot study we have evaluated for the deletion and/ mutation of Pfhrp2 and Pfhrp3 genes in RDT negative and microscopy positive blood samples in a tertiary care center in South India.

\section{Materials And Methods}

This was a descriptive study conducted in the Department of Microbiology, JIPMER in collaboration with the Departments of General Medicine and Paediatrics, JIPMER, Puducherry. The study was approved by the PGRMC committee and Institute ethics committee for human studies before the start of the study. The study period was for 2 years (Jan 2019- Dec 2020). The study was done on 2 subgroups of patients 
1) retrospective sub-group

2) prospective sub-group

\section{Inclusion criteria}

(1) All the stored blood samples (from 4/8/18 to 31/12/18) which were positive for P.falciparum by any one of the routine diagnostic tests for malaria (Peripheral blood smear examination / Quantitative buffy coat analysis( QBC) / Rapid diagnostic card (RDT) test were included (retrospective sub group)

(2) All patients with fever, chills and rigors, or suspected cases of malaria infection whose blood samples were tested positive for malaria by one or more of the following diagnostic methods- Peripheral blood smear examination / QBC/ Parasight ${ }^{\text {TM }}$ digital device/ RDT were included (prospective sub group)

\section{Exclusion criteria}

Febrile patients diagnosed with other infectious diseases (dengue, enteric fever, chikungunya etc.).

\section{Sample size calculation}

Since this was a pilot study to test for the deletion/mutation of pfhrp2 and / pfhrp3 genes in the $P$. falciparum positive blood samples in Puducherry and as Puducherry mostly falls under the $P$. vivax belt, we included all the samples which were tested positive for Plasmodium species during the time period of 2 years (Jan 2019 - Dec 2020) along with all the stored positive blood samples from August 2018 - December 2018.

\section{Study procedure}

All the stored positive blood samples included in the retrospective subgroup were de-identified by removing the hospital number and were given consecutive random numbers by the lab technician and then the samples were taken for the study. No contact was made with these patients. Only the demographic and clinical details along with the test results of peripheral smear examination, QBC and RDTs were obtained from the records. However, in the prospective subgroup, blood samples from patients attending outpatient/inpatient (OPD/IPD) departments or Emergency Medical Services (EMS) and patients who presented with fever, chills and rigors or suspected malarial infection whose blood samples were sent in EDTA tubes to the Department of Microbiology for diagnostic testing for peripheral smear, QBC, RDT or Parasight ${ }^{\text {TM }}$ digital device were noted. The blood samples collected were aliquoted into 2 separate vials, one used for the routine diagnostic tests as which includes peripheral blood smear, quantitative buffy coat analysis, Parasight ${ }^{\mathrm{TM}}$ digital device and other for molecular analysis stored in deep freezer $\left(-80^{\circ} \mathrm{C}\right)$.

\section{Routine diagnostic assays performed :}

Both thick and thin peripheral smear were performed and screened.QBC were performed using a commercially available kit and the RDT used were SD Bio line Malaria Antigen P.f./ P.v (Bio Standard Diagnostics Pvt. Ltd. India). Appearance of only control band in the RDT card indicates that the test sample is negative, $P . f$ band indicates that the samples is positive for P.falciparum and P.v band indicates that the sample is positive for Plasmodium species other than P. falciparum i.e.P.vivax/malariae/ ovale. Parasight ${ }^{\text {TM }}$ digital device (Sight Diagnostics, Israel) is a computerised method for malaria diagnosis available with a desktop system. EDTA blood sample is preferred of which $5 \mu$ l was mixed with that of the fluorescent stain solution provided and from the mixture $35 \mu \mathrm{l}$ was loaded into the chamber row of the cartridge provided to form monolayer of the blood cells. A single cartridge can hold 5 samples at a time. This cartridge is then loaded into the machine and the monolayer of the blood were analysed under high resolution imaging by tripartite wavelength excitation for RBCs,WBCs,platelets,various morphological forms of malarial parasites like ring forms,gametocytes,schizonts. Among all 
the samples whichever was tested positive for Plasmodium species by any one of the above mentioned routine diagnostic methods were enrolled in the study subsequently after getting informed and written consent from those patients. A detailed history including the clinical presentations were obtained from these patients using a study proforma.

\section{Speciation PCR:}

All these Plasmodium species positive retrospective and prospective subgroup samples enrolled in the study were subjected for speciation PCR targeting 18SrRNA (Kumar N et al. 2013).QIAamp DNA blood mini kit (Qiagen, Germany) for extraction was used to extract the genomic DNA from $200 \mu \mathrm{L}$ of whole blood samples and the procedure was performed according to the manufacturer's protocol. The extracts were stored in $-20^{\circ} \mathrm{C}$ for further processing. It was a 2 step amplification process which included genus PCR using $2 \mu \mathrm{L}$ of the DNA extract followed by species PCR using $2 \mu \mathrm{L}$ of the first round PCR product. The details of the genus specific and species specific primers used were given in Table 1 and 2 (Kumar $\mathrm{N}$ et al. 2013). The cycling conditions used were given in Table3. The quality of the genomic DNA extracted were checked using the amplification of an additional protein called $P$. falciparum merozoite surface protein 1 ).2 $\mu \mathrm{L}$ of the genomic DNA was used as the template for the primary step and $2 \mu \mathrm{L}$ of the 1:10 diluted PCR product of the primary step were used for the nested step of the PCR. All the PCR reactions were performed in a reaction mixture of $25 \mu \mathrm{L}$. Post PCR analysis of the products was done using $1.2 \%$ agarose electrophoresis run at 100 volts for about 50 minutes and our products of interest were checked and noted using GelDoc-lt2 imager.

Table 1

Plasmodium species specific PCR primers

\begin{tabular}{|ll|}
\hline Plasmodium genus specific PCR primers & Primer Sequence \\
\hline rPLU1 & F: TCAAAGATTAAGCCATGCAAGTGA \\
\hline rPLU5 & R: CCTGTTGTTGCCTTAAACTTC \\
\hline
\end{tabular}

Table 2

Plasmodium species specific PCR primers

\begin{tabular}{|c|c|c|}
\hline \multicolumn{2}{|c|}{ Species specific PCR primers } & \multirow{2}{*}{$\begin{array}{l}\text { Primer Sequence } \\
\text { F: TTAAACTGGTTTGGGAAAACCAAATATATT }\end{array}$} \\
\hline P.falciparum (206 bp) & rFAL1 & \\
\hline & rFAL2 & R: ACACAATGAACTCAATCATGACTACCCGTC \\
\hline \multirow[t]{2}{*}{ P.vivax (121 bp) } & rVIV1 & F: CGCTTCTAGCTTAATCCACATAACTGATAC \\
\hline & rVIV2 & R:ACTTCCAAGCCGAAGCAAAGAAAGTCCTTA \\
\hline \multirow[t]{2}{*}{ P.ovale (226 bp) } & rOVA1 & F:ATCTCTTTTGCTATTTTTTAGTATTGGAGA \\
\hline & rPLU2 & R:ATCTAAGAATTTCACСTCTGACATCTG \\
\hline \multirow[t]{2}{*}{ P.malariae (145 bp) } & rMAL1 & F: ATAACATAGTTGTACGTTAAGAATAACCGC \\
\hline & rMAL2 & R:AAAATTCCCATGCATAAAAAATTATACAAA \\
\hline
\end{tabular}

Pfhrp 2/3 flanking genes PCR : 
Once the species is confirmed,blood samples that are positive for Plasmodium falciparum by microscopy and speciation PCR but negative by RDT were subjected for the amplification of the pfhrp2,pfhrp 3 and their flanking genes ( $p f h r p 2$ upstream, pfhrp2 downstream, and pfhrp3 upstream, pfhrp3 downstream) by conventional PCR and the patterns of gene deletions were noted (Pati, Pet al. 2018). The controls used were Genomic DNA from Plasmodium falciparum strain Dd2 that lacks pfhrp2 and its flanking genes and HB3 that lacks pfhrp3 and its flanking genes (Pati, Pet al.2013). These controls were ordered and obtained from the BEI resources. The primers used and the cycling conditions were shown in Tables 4 and 5.The amplified products were analysed using 1.5\% agarose gel electrophoresis run at 100 volts for about 50 minutes and our products of interest were checked and noted.Apart from this to confirm the presence of pfhrp2 gene in RDT positive P.falciparum samples, 2 samples that were RDT positive for P.falciparum were randomly selected and amplification of the pfhrp2 exon region were done.The products of PCR amplification were subjected to sequencing using ABI3730 XL sequencer (Applied bio system, Foster, CA, USA) at Eurofins genomics private limited, India. The sequences generated were assembled and compared using the BLAST (Basic Local Alignment Search Tool) of NCBI. Translation of DNA sequences into protein sequences were done using EXPASY TRANSLATE and the translated protein sequences were assembled and compared using Protein Basic Local Alignment Search Tool (pBLAST) of NCBI.

Table 3

The cycling conditions of the genus and species specific PCR:

\begin{tabular}{|c|c|c|}
\hline Cycling conditions & $\begin{array}{l}\text { Genus PCR } \\
\text { Duration }\end{array}$ & $\begin{array}{l}\text { Species PCR } \\
\text { Duration }\end{array}$ \\
\hline Hot start $95^{\circ} \mathrm{C}$ & 5 minutes & 5 minutes \\
\hline Denaturation $94^{\circ} \mathrm{C}$ & 1 minutes & 1 minutes \\
\hline Annealing $58^{\circ} \mathrm{C}$ & 2 minutes & 30 seconds \\
\hline Elongation $72^{\circ} \mathrm{C}$ & 2 minutes & 30 seconds \\
\hline End cycle elongation $72^{\circ} \mathrm{C}$ & 10 minutes & 8 minutes \\
\hline
\end{tabular}


Primers and cycling conditions details for the pfhrp2 and its flanking genes (Pati, $P$ et al 2013):

\begin{tabular}{|c|c|c|c|}
\hline pfhrp 2 and its flanking genes & Primer sequences & $\begin{array}{l}\text { Annealing temperature } \\
\text { (1 min) }\end{array}$ & No.of cycles \\
\hline \multirow[t]{2}{*}{ pfhrp2-2 } & F: CAAAAGGACTTAATTTAAATAAGAG & \multirow[t]{2}{*}{$55^{0} \mathrm{C}$} & \multirow[t]{2}{*}{35} \\
\hline & R: AATAAATTTAATGGCGTAGGCA & & \\
\hline \multirow[t]{2}{*}{ pfhrp 2-12 (primary) } & F: GGTTTCCTTCTCAAAAAATAAAG & \multirow[t]{2}{*}{$55^{0} \mathrm{C}$} & \multirow[t]{2}{*}{35} \\
\hline & R: TCTACATGTGCTTGAGTTTCG & & \\
\hline \multirow[t]{2}{*}{ pfhrp 2-12 (nested) } & F: GTATTATCCGCTGCCGTTTTTGCC & \multirow[t]{2}{*}{$63^{\circ} \mathrm{C}$} & \multirow[t]{2}{*}{25} \\
\hline & R: CTACACAAGTTATTATTAAATGCGGAA & & \\
\hline \multirow[t]{2}{*}{ (MAL7P1.230) (Primary } & F: GATATCATTAGAAAACAAGAGCTTAG & \multirow[t]{2}{*}{$63^{0} \mathrm{C}$} & \multirow[t]{2}{*}{35} \\
\hline & R: TATCCAATCCTTCCTTTGCAACACC & & \\
\hline \multirow[t]{2}{*}{ (MAL7P1.230) (Nested) } & F: TATGAACGCAATTTAAGTGAGGCAG & \multirow[t]{2}{*}{$65^{0} \mathrm{C}$} & \multirow[t]{2}{*}{25} \\
\hline & R: TATCCAATCCTTCCTTTGCAACACC & & \\
\hline \multirow[t]{2}{*}{ (MAL7P1.228) (Primary } & F: AGACAAGCTACCAAAGATGCAGGTG & \multirow[t]{2}{*}{$60^{\circ} \mathrm{C}$} & \multirow[t]{2}{*}{35} \\
\hline & R: TAAATGTGTATCTCCTGAGGTAGC & & \\
\hline \multirow[t]{2}{*}{ (MAL7P1.228) (Nested) } & F: CCATTGCTGGTTTAAATGTTTTAAG & \multirow[t]{2}{*}{$63^{0} \mathrm{C}$} & \multirow[t]{2}{*}{25} \\
\hline & R: TAAATGTGTATCTCCTGAGGTAGC & & \\
\hline
\end{tabular}

Table 5: Primers and cycling conditions details for the pfhrp3 and its flanking genes [10]: 


\begin{tabular}{|c|c|c|c|}
\hline pfhrp 3 and its flanking genes & Primer sequences & $\begin{array}{l}\text { Annealing temperature } \\
\text { (1 min) }\end{array}$ & No.of cycles \\
\hline \multirow[t]{2}{*}{ pfhrp3-2 } & F: AATGCAAAAGGACTTAATTC & \multirow[t]{2}{*}{$55^{0} \mathrm{C}$} & \multirow[t]{2}{*}{35} \\
\hline & R: TGGTGTAAGTGATGCGTAGT & & \\
\hline \multirow[t]{2}{*}{ pfhrp 3-12 (primary) } & F: GGTTTCCTTCTCAAAAAATAAAA & \multirow[t]{2}{*}{$55^{0} \mathrm{C}$} & \multirow[t]{2}{*}{25} \\
\hline & R: CCTGCATGTGCTTGACTTTA & & \\
\hline \multirow[t]{2}{*}{ pfhrp 3-12 (nested) } & F: ATATTATCGCTGCCGTTTTTGCT & \multirow[t]{2}{*}{$62^{\circ} \mathrm{C}$} & \multirow[t]{2}{*}{30} \\
\hline & R: CTAAACAAGTTATTGTTAAATTCGGAG & & \\
\hline \multirow[t]{2}{*}{ (MAL13P1.485) (Primary) } & F: TTGAGTGCAATGATGAGTGGAG & \multirow[t]{2}{*}{$60^{\circ} \mathrm{C}$} & \multirow[t]{2}{*}{35} \\
\hline & R: AAATCATTTCCTTTTAACACTAGTGC & & \\
\hline \multirow[t]{2}{*}{ (MAL13P1.485) (Nested) } & F: GTTACTACATTAGTGATGCATTC & \multirow[t]{2}{*}{$60^{\circ} \mathrm{C}$} & \multirow[t]{2}{*}{25} \\
\hline & R: AAATCATTTCCTTTTACACTAGTGC & & \\
\hline \multirow[t]{2}{*}{ (MAL13P1.475) (Primary) } & F: TTCATGAGTAGATGTCCTAGGAG & \multirow[t]{2}{*}{$55^{0} \mathrm{C}$} & \multirow[t]{2}{*}{35} \\
\hline & R: TCGTACAATTCATCATACTCACC & & \\
\hline \multirow[t]{2}{*}{ (MAL13P1.475) (Nested) } & F: TTCATGAGTAGATGTCCTAGGAG & \multirow[t]{2}{*}{$61^{\circ} \mathrm{C}$} & \multirow[t]{2}{*}{25} \\
\hline & R: GGATGTTTCGACATTTTCGTCG & & \\
\hline
\end{tabular}

All the P.falciparum positive patients were followed up weekly for 4 consecutive weeks following diagnosis of malaria using a structured proforma. The different clinical features and the clinical outcome of the patients with pfhrp $2 / 3$ gene deletion or mutation were compared with that of the clinical outcome of the patients without such deletion or mutation to look for any difference in the clinical outcome between the 2 sub-groups. The workflow is shown in the flowchart (Fig. 1).

\section{Statistical analysis:}

The data collected were entered and analysed in STATA software, version 14.0. Continuous variables like age, duration of illness, were summarized as mean/ median depending on the distribution of the data. Categorical variables like gender, socioeconomic status, various clinical characteristics like fever, chills and rigors, headache, jaundice, myalgia, and various complications like bleeding, seizures, chest pain unconsciousness, low urine output etc., species of Plasmodium causing infection, treatment modality were expressed as percentage. Outcome variables like $p$ fhrp $2 \& / 3$ gene deletion or mutation and negative RDT in patients with pfhrp2\&/3 gene deletion in PCR were expressed as percentage with $95 \%$ confidence interval. Difference in the outcome between the patients with $p$ fhrp $2 \& / 3$ gene deletion or mutation and the patients with no such deletion were done using chi square test.

\section{Results}

A total of 63 samples were enrolled in the study of which 28 were retrospective stored positive samples for Plasmodium species and 35 were prospectively collected positive samples for Plasmodium species. The mean age of the patients enrolled were found to be $30.57 \pm 15.5$ years (mean age \pm SD). The distribution of the malaria infection were found to be higher among males $44 / 63(69.84 \%)$ than in females $19 / 63(30.16 \%)$. Most of the patients were adults $56 / 63$ (89\%) and only $7 / 63(11 \%)$ belonged to pediatric population. None of them were migrant workers. Majority of the enrolled patients were found to be from Tamil Nadu especially from Villupuram 38/63 (60\%) followed by Cuddalore 13/63 (21\%) and only $4 / 63(6 \%)$ were from Puducherry. It was also observed that the most common clinical presentations among these patients 
were fever (100\%), headache (84\%) and myalgia (73\%) followed by the others (Fig. 2). None of the patients had past history of malaria and had not taken treatment for malaria.

Fifty samples out of the total 63 (79\%) were found to be positive for P.vivaxand the remaining 13/63(21\%) were found to be positive for P.falciparum by nested speciation PCR targeting 18S rRNA gene of all the Plasmodium species (P. falciparum, P.vivax, P. malariae, P. ovale, and P. knowlesi) (Fig. 3).P.vivax was identified with the base pair size of 121 and P.falciparum were identified with the base pair size of 209 (Fig. 4 and 5). No other species of Plasmodium besides P.falciparum and P.vivax were found to cause infection and also no mixed infection were identified.Additional pfmsp1gene amplification was also done for all P.falciparum samples to check for the quality of the DNA isolated.Various other tests done and their results were provided in the Table 6.Of all the methods done, high positivity (97\%) was found with the peripheral smear examination by microscopy followed by RDT (94\%) and QBC (87\%).Parasight ${ }^{\mathrm{TM}}$ test were performed only for the 35 prospective samples out of which 33 (94\%) were found to be positive for Plasmodium species. Among these 33 samples 7 samples were identified as P.falciparum and 26 samples were identified as P.vivax.Of the 50 samples that were tested positive for P.vivax by PCR, all were tested positive by RDT also, whereas of the 13 samples that were tested positive for P.falciparum by PCR, only 9 were tested positive by RDT and remaining 4 were tested negative by RDT but positive by peripheral smear examination for Plasmodium falciparum. Table 7shows the comparison of speciation PCR and the RDT results done with the help of Chi square test and it was found to be statistically significant with a ' $P$ value of 0.00 '.

Table 6

Comparison of RDT/PS/QBC and PCR RESULTS:

\begin{tabular}{|lllllll|}
\hline Tests & $\begin{array}{l}\text { P.falciparum } \\
(\mathbf{n = 1 3})\end{array}$ & & $\begin{array}{l}\text { P.vivax } \\
(\mathbf{n = 5 0})\end{array}$ & & \multicolumn{2}{l|}{$\begin{array}{l}\text { Overall } \\
(\mathbf{n}=63)\end{array}$} \\
\cline { 2 - 7 } & POSITIVE & NEGATIVE & POSITIVE & NEGATIVE & POSITIVE & NEGATIVE \\
\hline Rapid diagnostic card tests (RDT) & 9 & 4 & 50 & nil & $59 / 63$ & $4 / 63$ \\
& $(14.29 \%)$ & $(6.35 \%)$ & $(79.37 \%)$ & & $(94 \%)$ & $(6 \%)$ \\
\hline Peripheral smear & 13 & nil & 48 & 2 & $61 / 63$ & $2 / 63$ \\
(Thin smear and thick smear) & $(20.63 \%)$ & & $(76.19 \%)$ & $(3.17 \%)$ & $(97 \%)$ & $(3 \%)$ \\
\hline Quantitative buffy coat analysis & 13 & nil & 42 & 8 & $55 / 63$ & $8 / 63$ \\
& $(20.63 \%)$ & & $(66.67 \%)$ & $(12.70 \%)$ & $(87 \%)$ & $(13 \%)$ \\
\hline Speciation PCR & 13 & nil & 50 & nil & $63 / 63$ & nil \\
& $(20.63 \%)$ & & $(79.37 \%)$ & & $(100 \%)$ & \\
\hline
\end{tabular}

Table 7

Comparison of RDT and PCR results:

\begin{tabular}{|llll|}
\hline PCR Results(n=63) & $\begin{array}{l}\text { RDT results } \\
(n=63)\end{array}$ & \\
& Positive for P.falciparum & Positive for P.vivax & Negative for both \\
\hline P.falciparum $(n=13)$ & $9(69 \%)$ & nil & $4(31 \%)$ \\
\hline P.vivax $(n=50)$ & nil & $50(100 \%)$ & nil \\
\hline
\end{tabular}

${ }^{*}$ Chi square test 
P.falciparum RDT positive samples were also amplified by PCR for pfhrp2 genes to confirm its presence. The amplicons of randomly selected 2 samples that amplified pfhrp2-2 were sent to Eurofins, Bangalore for sequencing and the results confirmed the presence of pfhrp2gene in them. The sequences were submitted to NCBI database (Genbank). The accession numbers areOK236567 and OK424756.For the 4 samples that are positive for P.falciparum by microscopy and PCR but negative by RDT were amplified for pfhrp2, pfhrp3 and their flanking genes to look for the deletion of one or more genes by PCR. It was observed that all the four samples were negative for pfhrp2-2, pfhrp3-2 exon regions and pfhrp3-12 region. Amplification of the flanking genes showed that one sample out of these 4 samples were negative for both upstream (MAL7P1.230) and downstream (MAL7P1.228) gene of pfhrp2 and upstream (MAL13P1.485) gene of $p f h r p 3 . T h e$ PCR images of the amplification of the pfhrp2, pfhrp3 and its flanking genes were shown in figures 6,7 and 8.The pattern of gene deletion observed in these 4 RDT negative but speciation PCR positive samples were shown in table 8.The clinical presentation and the clinical outcome during the follow up were compared between the patients with and without $p f h r p 2 / 3$ gene deletion or mutation and no statistically significant difference in the outcome were observed between the 2 groups (Table 9).

Table 8: Pattern of pfhrp2, pfhrp3 and its flanking gene deletion observed

\begin{tabular}{|c|c|c|c|c|c|c|c|c|}
\hline \multirow{2}{*}{$\begin{array}{l}\text { Test } \\
\text { samples } \\
\text { (PfRDT- } \\
\text { PCR +) }\end{array}$} & \multicolumn{4}{|c|}{ Pfhrp2 and its flanking gene PCR } & \multicolumn{4}{|c|}{ Pfhrp3 and its flanking gene PCR } \\
\hline & $\begin{array}{l}\text { Pfhrp2- } \\
2\end{array}$ & $\begin{array}{l}\text { Pfhrp2- } \\
12\end{array}$ & MAL7P1.230 & MAL7P1.228 & $\begin{array}{l}\text { Pfhrp3- } \\
2\end{array}$ & $\begin{array}{l}\text { Pfhrp3- } \\
12\end{array}$ & MAL13P1.485 & MAL13P1.475 \\
\hline $\mathrm{T} 1$ & - & + & - & - & - & - & - & + \\
\hline $\mathrm{T} 2$ & - & + & + & + & - & - & + & + \\
\hline T3 & - & + & + & + & - & - & + & + \\
\hline T4 & - & + & + & + & - & - & + & + \\
\hline
\end{tabular}

Table 9:Comparison of clinical features between patients with and without $p f h r p 2 / 3$ and its flanking gene deletion/mutation

\begin{tabular}{|ll|}
\hline Clinical features & P.value (compared between patients with and without $p$ fhrp2/3 gene deletion/mutation) \\
\hline Sweat & 0.48 \\
\hline Chills and rigors & 0.1 \\
\hline Headache & 0.9 \\
\hline Abdominal pain & 0.16 \\
\hline Myalgia & 0.76 \\
\hline Jaundice & 0.317 \\
\hline Anaemia & 0.85 \\
\hline Unconsciousness & 0.11 \\
\hline Low Urine output & 0.11 \\
\hline Comorbidities & 0.52 \\
\hline
\end{tabular}




\section{Discussion}

Early diagnosis of malaria and the initiation of treatment plays an essential role in preventing the complications and thereby reducing the mortality caused by the disease. Rapid diagnostic tests targeting various malarial antigens like PfHRP 2 and 3 , pan malarial aldolase, lactate dehydrogenase were introduced particularly to aid for early diagnosis in the remote areas where quality microscopy is not available. pfhrp2 gene that codes for P.falciparum specific PfHRP2antigenis located on chromosome 8 and pfhrp3 gene that codes for PfHRP3 antigen (which is the structural analogue of $p f h r p 2$ ) is on chromosome 13(Fontecha, G et al., 2018, Nderu, D et al., 2019).Spread of the P.falciparum isolates that lacks or fails to express $p f h r p 2 / 3$ genes due to genetic mutation or gene deletion is threatening the reliability of the use of $p f h r p 2 / 3$ based RDTs in P.falciparum diagnosis mainly in the malaria endemic areas (Nderu, D et al., 2019). Hence, analysing the genetic diversity of $p f h r p 2 / 3$ genes is an essential component in malaria control.

In our study, all the age groups were found to be affected by malaria with the mean age affected being 30.57 years \pm 15.5 years. In a study done by Dayanandet al., ata tertiary care centre in Mangaluru, south India also found that the mean age affected by malaria were 33.4 years and 36 years respectively which is closely related to our study (Ismail, I.M et al., 2019 and Dayanandet al.,2017).This shows that the middle aged working people are at higher risk of acquiring malaria than the extremes of age groups. The distribution of the malaria infection were higher among males 44/63(69.84\%) than in females $19 / 63(30.16 \%)$. In concordance with this, male preponderance in malaria were seen in a couple of other studies also, where 74.2\% and 73.3\% affected were males (study (Ismail, I.M et al., 2019 and Dayanandet al.,2017), which is most probably due to high exposure associated with their work.Most of the patients enrolled in our study belonged to lower and upper lower socioeconomic status which is in concordance with the other studies which showed that people of lower socio economic group are at higher risk of acquiring malaria (Das et al.,2020 and malaria site 2015). Majority of the enrolled patients were found to be from Tamil Nadu especially from Villupuram $(38 / 63,60 \%)$ followedby Cuddalore $(13 / 63,21 \%)$ and only $4 / 63(6 \%)$ were from Puducherry.Most of the patients (42/63, 65\%) were found to be residents of rural areas and none of the enrolled patients were found to be migrants from other endemic regions for malaria. This shows that the residents of rural areas are at higher risk for acquiring malaria than urban areas which is in concordance with the other studies where more than $90-95 \%$ and $<5-10 \%$ cases were reported from rural areas and urban areas respectively (malaria site 2015).Among the 4 patients out of 63 patients enrolled in whom pfhrp $2 / 3$ gene deletions were observed, 3 patients were found to be residents of Cuddalore and 1 patient was from Puducherry. This clearly showed that Cuddalore might harbour the strains of P.falciparum that lack $p f h r p 2 / 3$ gene due to deletion or mutations. Since from south India no study was done on $p f h r p 2 / 3$ gene deletion or mutation(s), we could not compare this observation with similar studies. However, it is an important to note that Cuddalore in Tamil Nadu also have pfhrp2/3 gene deleted P.falciparum which needs to be studied further. But there are other Indian studies on pfhrp2/3 deletion which includes the one done by Bharti P.K et al.,2017 ,at eight endemic states of malaria in which highest proportion of pfhrp2/3 deletion were observed in Gujarat (8\%), Orissa (4.8\%) and Jharkhand (1.7\%) (Bharti P.K et al., 2017). In general, patients with malaria will present with diverse clinical symptoms and may range from mild headache to serious complications (Pinheirob, V.Eet al.,1993).In our study, all the patients presented with fever (100\%) and most of the patients also had chills and rigors (71\%), headache (84\%) and myalgia (73\%) while rest of the symptoms like abdominal pain, anemia, jaundice, less urine output, bleeding etc. were less frequent. It is known that the clinical presentation in malaria is nonspecific and mostly will mimic any other viral illness in the initial stages (Dayanand KK et al.,2017 ,Trampuz, Aet al., 2003)and similar presentation were observed in our study also. Of the total 63 patients, 12 (19\%) patients developed mild complications due to malaria which includes anemia and jaundice. Majority of the patients who developed complications (8/12) were infected with P.falciparum and only (4/12) were infected with P.vivax. This observation from our study is in concordance with other studies which had shown that severity and complications are more with P.falciparum than with other species of Plasmodium that causes infection (Trampuz, Aet al., 2003, World Health Organization, 2000).Similar to P.falciparum, P.vivaxalso has been found to result in serious complications recently. A study conducted in Mumbai by Limaye CS et al.,2012had found that monoinfection with P.vivaxresulted in severe malaria with leukopenia, thrombocytopenia, acute respiratory distress, hypotension in about $31 \%$ of the cases.Many other studies also

Page $10 / 22$ 
have proved that severe malaria and multiorgan failure can happen in P.vivax infection also (Makkar, R.P.Set al., 2002,Mehndiratta, Set al., 2013)

Comparison of clinical features between the patients with pfhrp2/3 gene deletion and patients without such deletions showed no significant differences but all four patients with proven $p$ fhrp $2 / 3$ gene deletion had suffered from complications like jaundice, anemia, abdominal pain and among them one was a child who developed severe complications like decreased urine output, unconsciousness and died during follow up on 2nd week of illness. However, as studies which compared the clinical course and outcome of pfhrp2/3 deleted or mutated P.falciparum infected patients with the other patients are scarce, it is very difficult to compare this finding with other studies. However, we can definitely infer that $p$ fhrp $2 / 3$ deleted or mutated P.falciparuminfection mostly will present with some complications like anemia, jaundice as all our 4 patients suffered from complications in our study.

In the peripheral smear microscopy by thick and thin film methods, early stages of the malarial parasites like ring forms (85\%) were more commonly observed than gametocytes in P.falciparum positive patients. Similarly, ring forms and trophozoites(90\%) were seen in majority than schizonts and gametocytes in P.vivax positive patients. This confirms that most of the patient presented with recent infection and not past infection as the early rings forms and trophozoite forms are seen in RBCs that are recently infected. These asexual erythrocytic stages are responsible for the clinical manifestations and those commonly observed in the patients includefever,chills, myalgia etc.,. The gametocytes themselves are not much involved in the pathogenesis of the disease but they are the exclusive forms taken up by the mosquitoes and is responsible for the spread of the disease(Kozicki, M et al 2017, Meibalan, E. and Marti, M., 2017, Roberts CH et al., 2013).

In our study, of the 63 samples collected, 50 (79\%) were found to be P.vivax and 13 (21\%) were found to be P.falciparum by conventional nested PCR targeting 18SrRNA. This showedthat P.vivaxwas the most common species causing malaria in our region than P.falciparumfrom the study. No other species of Plasmodium were found to cause infection among our study population and hence our setting. Distribution of P.vivax and P.falciparumis complex andvaries across our country, but overall burden of P.vivax is more than P.falciparum. It was found that majority of the urban areas are commonly affected by P.vivax whereas P.falciparum is predominantly reported from Odisha and north-eastern states (Anvikar, A.R.et al., 2016).Though peripheral smear examination remains the gold standard for malaria diagnosis, asymptomatic malaria cases and low parasitemia cases are usually missed by this method. PCR when compared to microscopy and RDT is more sensitive and specific for malaria diagnosis [Miguel-Oteo, M et al.,2017,Rubio, J.Met al.,2002,Pakalapati, D et al 2013).Despite the fact that malaria cases have decreased in recent years, the proportion of $P$. vivax cases has increased gradually (Anvikar, A.R.et al., 2016).In a malaria prevalence study conducted duringJune 2011-December 2012 covering many endemic states of malaria including Tamil Nadu, found that, west, central, east, and north east India were predominantly infected with $P$. falciparum while $P$. vivax infection was predominant in north and south India (Haanshuus, C.Get al., 2016).In contrast to our study, $P$. falciparum was found in 46 percent of malaria positive patients, while $P$. vivax was found in 38 percent, mixed infections with $P$. falciparum and $P$. vivax were found in 11 percent, and $P$. malariae was found in $5 \%$ in this study(Singh, Vet al.,2009). The reason for this could be due to chloroquine resistance in $P$. falciparum which lead to increased incidence of $P$. falciparum in comparison to $P$. vivax over the last 30 years (Haanshuus, C.Get al., 2016,Singh, Vet al.,2009,Krishna, S et al., 2015).In another large epidemiological study conducted by Siwal $\mathrm{N}$ et al.,involving 9 different endemic states of malaria in India extending from north to south and east to west showed that the ratio of $P$. falciparum to $P$. vivax was 49:51, with mixed species infections due to these two parasites accounting for $13 \%$ of overall infection (Siwal, Net al., 2018).

To identify malaria parasites to the species level, PCR-based amplification assays such as nested PCR (Singh, $B$ et al.,1999) semi nested PCR (Rubio, J.Met al., 1999), multiplex PCR (Kho, W.Get al., 2003,Padley, Det al.,2003,Patsoula, Eet al.,2003) real-time or quantitative PCR (qPCR) (Perandin, Fet al., 2004,Rougemont, Met al., 2004 ), and more recently, loop-mediated isothermal amplification (LAMP) (Han, E.Tet al., 2007) have been created.PCR cannot replace traditional diagnostic methods in point-of-care diagnosis because it is relatively costly, resource-intensive, and time-consuming. On the other hand,

Page $11 / 22$ 
using PCR as a reference method offers more accurate data on prevalence and species distribution.Additional amplification of Pfmsp1 protein (Plasmodium falciparummerozoite surface protein 1) also have been checked to make sure that enough concentration of the parasitic DNA is available in the extract to amplify the pfhrp2/3 and its flanking genes. All the 14 samples that were positive for P.falciparum by microscopy and speciation PCR showed amplification of $p f m s p 1$ gene. Since Puducherry is not endemic for P.falciparum and it falls mostly under P.vivax belt, we could get only 14 samples tested positive for P.falciparum of which 9 were prospectively collected and 4 were retrospectively stored positive samples.

In our study, of the 63 samples, conventional speciation PCR targeting 18SrRNA showed 50 samples to be P.vivax positive and 14 samples to be P.falciparum positive.Among these positive samples 4/68 (31\%) were negative by RDT and comparing both speciation PCR and RDT tests using chi square test showed that it was statistically significant with the P value of 0.00 . The prevalence of pfhrp $2 / 3$ genes deletion in our study was around $31 \%$ which was higher when compared to the other Indian studies on genetic diversity of pfhpr2/3 genes (Kumar, $\mathrm{N}$ et al., 2013 and Bharti PK et al., 2016). In India the first evidence of the existence of pfhrp2/3 deletion was done by Kumar et al., done in Chhattisgarh, Bilaspur district on December 2010 where 2 samples out of the 48 (4\%) samples were found to lack both pfhrp2/3 genes (Kumar, $\mathrm{N}$ et al., 2013.)Another Indian study by Bharti et al., done in 16 sites of eight endemic states for malaria in India on July - Dec 2014 found that $2.4 \%$ lacked pfhrp2 gene and 1.8\% lacked pfhrp3 gene and both pfhrp2 and 3 gene deletions which highest were from Gujarat with 8\%(Bharti PK et al., 2016). This study provides evidence for low level presence of pfhrp2 and pfhrp3 deleted P.falciparum parasites in different endemic regions of India. In another Indian study conducted over 25 districts of Orissa found that $65.5 \%$ of the study samples were pfhrp 2 negative, and 41.4 percent were pfhrp 3 negative, with $29 \%$ being dual negative (Golassa, Let al., 2020). Ours is the first south Indian study done on $p f h r p 2 / 3$ gene deletion or mutation in P.falciparum positive samples and we found $31 \%$ of the samples do not carry both $p f h r p 2 / 3$ genes by conventional PCR.Analysing other similar studies conducted in other countries, various studies conducted in African regions also have reported higher percentage of pfhrp2 and 3 gene deletions which were in concordance to our study (Golassa, Let al.,2020,Iriart, Xet al.,2020 ,Menegon, M et al, 2017 and Nagata .N et al., 2012).In 2008-2009,Abdallah et al.,found that all 68 samples included in their study have amplified pfhrp2 and its flanking genes successfully, though few samples showed deletion of pfhrp3 and its flanking genes and hence they concluded that PfHRP2-based RDTs can be considered reliable in their geographical area(Abdallah, J.Fet al.,2015).Surprisingly within 2 years (2011), 40\% of the samples collected in the same region showed pfhrp2 gene deletion and the reasons for this were proposed to be due to the selective adaptation of the parasite in a short period of time and also the samples would have been collected only from few regions(Fontecha, G..et al.,2018)The comparison of frequency of pfhrp2 and pfhrp3 gene deletion cannot be concluded from our study as all the 4 samples lacked both the genes. A WHO world malaria threat map showing worldwide survey of $p f h r p 2 / 3$ and its flanking gene status, observed as general rule that, deletion of pfhrp3was more frequent when compared to that of pfhrp2 (WHO Malaria Threats Map ). One exception is in Suriname, where out of the 78 isolates , $14 \%$ were pfhrp2-negative while $4 \%$ were pfhrp3-negative(AkinyiOkoth, S et al., 2015).Also similar trend were seen in few other studies conducted in Peru, Colombia, and Honduras where the proportion of pfhrp3 gene deletion was more common than pfhrp2 (Akinyi, Set al 2013 and Gamboa, D et al., 2010).Other similar studies conducted in China - Myanmar border area by Peipei Li et al., found that 4 / 87 (4.6\%) lacked pfhrp2 gene and also 3 out of these 4 samples may also lack pfhpr3 gene in addition to pfhrp2 gene deletion (Maltha, Jet al., 2012).Studies conducted in various regions of central and south America showed varying prevalence of pfhrp2/3 gene deletion which is shown in Table 10.

\section{Table 10 : Various studies on $p$ fhrp $2 / 3$ gene deletion and mutation}




\begin{tabular}{|c|c|c|c|c|}
\hline Region & pfhrp2 deletion & pfhrp3 deletion & $\begin{array}{l}\text { Both pfhrp } 2 / 3 \\
\text { deletion }\end{array}$ & Study \\
\hline $\begin{array}{l}\text { Peru } \\
\text { (1998-2011) }\end{array}$ & $20-41 \%$ & $43-70 \%$ & $21-25 \%$ & $\begin{array}{l}\text { Gamboa } \\
(25,88,89)\end{array}$ and Maltha Jet al., \\
\hline $\begin{array}{l}\text { Colombia } \\
(1999-2009)\end{array}$ & $18 \%$ & $52 \%$ & $13 \%$ & $\begin{array}{l}\text { Dorado EJ and Murillo Solano C et } \\
\text { al.,(90,91) }\end{array}$ \\
\hline $\begin{array}{l}\text { Honduras } \\
\text { (2008-2009) }\end{array}$ & $0 \%$ & $44 \%$ & $0 \%$ & Abdallah JF et al.,(86) \\
\hline $\begin{array}{l}\text { Guyana } \\
(2010)\end{array}$ & $0 \%$ & $0 \%$ & $0 \%$ & Okoth SA et al.,(87) \\
\hline $\begin{array}{l}\text { Surinam } \\
(2009-2011)\end{array}$ & $14 \%$ & $4 \%$ & $2.1 \%$ & Okoth SA et al.,(87) \\
\hline $\begin{array}{l}\text { French Guyana } \\
(2009-2011)\end{array}$ & $0 \%$ & $7.4 \%$ & $0 \%$ & Trouvay M et al.,(92) \\
\hline Bolivia(2017) & $4 \%$ & $68 \%$ & $0 \%$ & RachidViana GM et al.,(93) \\
\hline $\begin{array}{l}3 \text { states from Brazil } \\
\text { (2017) }\end{array}$ & $0-31.1 \%$ & $18.3-68 \%$ & $0 \%$ & RachidViana GM et al.,(93,94) \\
\hline
\end{tabular}

Analysis of pfhrp $2 / 3$ genes of the 4 samples that were RDT negative but microscopy and PCR positive for P.falciparum showed that all 4 samples (31\%) lacked the pfhrp2 and 3 exon regions. Further amplification of the flanking genes of both pfhrp2/3 showed varying patterns of deletions i.e., All four samples did not amplify pfhrp3 1-2 region while one sample among these 4 samples did not amplify for pfhrp2 1-2 region, upstream(MAL7P1.230) and downstream (MAL7P1.228)gene of pfhrp2 and upstream (MAL13P1.485) gene of pfhrp3 also. This observation from our study confirms that even flanking genes deletions also exist in the circulating $P$. falciparumstrains. Different patterns of flanking gene deletions were also observed in other studies, where $86 \%$ of the isolates showed deletion of either pfhrp2 or pfhrp3, or their flanking genes (Bharti, P.K et al., 2016). In the same study, complete lack of pfhrp2 and its flanking genes were seen in $14 \%$ of the isolates showed while pfhrp3 and its flanking genes were present in all those 14 samples (Bharti, P.K et al., 2016). Similar to this, studies conducted in Brazil and Bolivia also have showed different combination of deletions of pfhrp2 and pfhrp3 flanking genes in 198 samples from Brazil and 25 samples from Bolivia (Rachid Viana, G.M., et al.,2017). Anotherstudy conducted in Columbia have observed sixteen different pfhrp2 and pfhrp3 and its flanking genes deletion patterns(Okoth, S.Aet al.,2015).At this time, it's unclear if the deletion of pfhrp2 and/or pfhrp3and its flanking genes are caused by a particular mechanism or by large chromosomal deletion events in specific regions of the genome where these genes are found (Okoth, S.Aet al.,2015). Hence, further research using next-generation sequencing methods is needed to determine the mechanisms underlying these genetic deletions.We have also compared the clinical presentation and follow up of the P.falciparum positive patients with pfhrp $2 / 3$ gene deletion and patients without such deletions which were not done in any of the studies related to $p$ fhrp $2 / 3$ gene deletion. The clinical features during the presentation and also the progress of the patient with the follow up after the start of treatment were done for 4 consecutive weeks to look for any changes in the pattern of clinical presentation. In our study, we could not find any significant difference in the clinical outcome of the patients with and without $p f h r p 2 / 3$ gene deletion. As other methods like microscopy, QBC, Parasight ${ }^{\mathrm{T}}$ digital deviceetc., were also performed in our set up to diagnose malaria, none of the cases were missed and also appropriate treatment were started as soon as possible which may be the reason for the similarity of the clinical outcomes observed between the two groups. Definitely, more studies with more number of patients with clinical follow up are needed especially in the remote areas where quality microscopy is not available to look for the actual difference in the clinical outcome of the disease. 


\section{Limitations of our study:}

Our study was done only with the limited number of sample size, collected within the time period of 2 years. The samples that have been received from the clinically suspected malaria cases attending our hospital only were included and there may be existence of these pfhrp2/3 deleted parasites even in the asymptomatic patients residing in the community which may have been missed. Hence, more studies with increased sample size and study period are needed to look for the existence of this pfhrp2/3 gene deleted Plasmodium falciparum in the community. This is essential to know the actual burden and clinical outcomes of such deletions and mutations. It is important to continue monitoring the proportion of pfhrp2-deleted $P$. falciparum parasites in various places of south India for its existence and its evolution pattern.

\section{Conclusion}

Our study have confirmed the molecular evidence of existence of pfhrp $2 / 3$ and its flanking genes deleted P.falciparum strains in south India especially in and around Puducherry. Hence, only PfHRP2/3 RDT based decision on diagnosis of P.falciparum malaria should always be reconsidered especially in remote areas.Supplementation with one of the other tests like microscopy/QBC/ Parasight ${ }^{\mathrm{TM}}$ digital devicewill help in improved diagnosis and early treatment.

\section{Declarations}

Funding : We sincerely thank JIPMER (Jawaharlal institute of post graduate medical education and research) for the financial support through the intramural research grant provided.

Competeing interests : The authors have no relevant financial or non financial interests to disclose.

Authors contributions: Dr.NonikaRajkumari ,the corresponding author had suggested the method of conducting this study and guided throughout the study to obtain appropriate results. Dr.MonikaSivaradjy have obtained the informed and written consent from the participants and performed all the conventional PCR mentioned this study and also analyed the results .Dr.Vamsimohan helps in the standardization of the PCR.Dr.FernandesMarieSharmila helped in the sequencing part of this study.Dr.AbdoulHamide and Dr.Sriram Krishnamurthy gave their valuable inputs needed in the analysis of the results.

Availability of data and materials :The datasets during and/or analysed during the current study available from the corresponding author on reasonable request.

Ethical approval \& consent to participate: The study was approved by the JIPMER Institute ethics committee for human studies before the start of the study. Informed and written consent were obtained from all the patients included in the study.

Consent : Written and informed consent were obtained from all the patients in the prospective group.

\section{References}

1. Abdallah, J.F., Okoth, S.A., Fontecha, G.A., Torres, R.E.M., Banegas, E.I., Matute, M.L., Bucheli, S.T.M., Goldman, I.F., de Oliveira, A.M., Barnwell, J.W. and Udhayakumar, V., 2015. Prevalence of pfhrp2 and pfhrp3 gene deletions in Puerto Lempira, Honduras. Malar. J., 14(1), pp.1-9.

2. AkinyiOkoth, S., Abdallah, J.F., Ceron, N., Adhin, M.R., Chandrabose, J., Krishnalall, K., Huber, C.S., Goldman, I.F., Macedo de Oliveira, A., Barnwell, J.W. and Udhayakumar, V., 2015. Variation in Plasmodium falciparum histidine-rich protein 2 (Pfhrp2) and Plasmodium falciparum histidine-rich protein 3 (Pfhrp3) gene deletions in Guyana and Suriname. PLoS One, 10(5), p.e0126805.

3. Akinyi, S., Hayden, T., Gamboa, D., Torres, K., Bendezu, J., Abdallah, J.F., Griffing, S.M., Quezada, W.M., Arrospide, N., De Oliveira, A.M. and Lucas, C., 2013. Multiple genetic origins of histidine-rich protein 2 gene deletion in Plasmodium 
falciparum parasites from Peru. Sci. Rep.,3(1), pp.1-8.

4. Anvikar, A.R., Shah, N., Dhariwal, A.C., Sonal, G.S., Pradhan, M.M., Ghosh, S.K. and Valecha, N., 2016. Epidemiology of Plasmodium vivax malaria in India. Am. J. Trop. Med., 95(6 Suppl), p.108.

5. Bharti, P.K., Chandel, H.S., Ahmad, A., Krishna, S., Udhayakumar, V. and Singh, N., 2016. Prevalence of pfhrp2 and/or pfhrp3 gene deletion in Plasmodium falciparum population in eight highly endemic states in India. PLoS One, 11(8), p.e0157949.

6. Dayanand, K.K., Punnath, K., Chandrashekar, V., Achur, R.N., Kakkilaya, S.B., Ghosh, S.K., Kumari, S. and Gowda, D.C., 2017. Malaria prevalence in Mangaluru city area in the southwestern coastal region of India. Malar. J, 16(1), pp.1-10.

7. Das, S., Rajkumari, N., Revathi, U. and Gururajan, A., 2020. Comparision of the various routine diagnostic modalities of malaria and a new method: the Parasight ${ }^{\text {TM }}$ platform. J Parasit Dis, 44(3), pp.528-535.

8. Fontecha, G., Mejía, R.E., Banegas, E., Ade, M.P., Mendoza, L., Ortiz, B., Sabillón, I., Alvarado, G., Matamoros, G.and Pinto, A., 2018. Deletions of pfhrp2 and pfhrp3 genes of Plasmodium falciparum from Honduras, Guatemala and Nicaragua. Malar. J,17(1), pp.1-10

9. Gamboa, D., Ho, M.F., Bendezu, J., Torres, K., Chiodini, P.L., Barnwell, J.W., Incardona, S., Perkins, M., Bell, D., McCarthy, J. and Cheng, Q., 2010. A large proportion of P. falciparum isolates in the Amazon region of Peru lack pfhrp2 and pfhrp3: implications for malaria rapid diagnostic tests. PLoS One, 5(1), p.e8091.

10. Golassa, L., Messele, A., Amambua-Ngwa, A. and Swedberg, G., 2020. High prevalence and extended deletions in Plasmodium falciparum hrp2/3 genomic loci in Ethiopia PLoS One, 15(11), p.e0241807.

11. Haanshuus, C.G., Chandy, S., Manoharan, A., Vivek, R., Mathai, D., Xena, D., Singh, A., Langeland, N., Blomberg, B., Vasanthan, G. and Sitaram, U., 2016. A high malaria prevalence identified by PCR among patients with acute undifferentiated fever in India. PLoS One, 11(7), p.e0158816

12. Han, E.T., Watanabe, R., Sattabongkot, J., Khuntirat, B., Sirichaisinthop, J., Iriko, H., Jin, L., Takeo, S. and Tsuboi, T., 2007. Detection of four Plasmodium species by genus-and species-specific loop-mediated isothermal amplification for clinical diagnosis. J. Clin. Microbiol, 45(8), pp.2521-2528.

13. Iriart, X., Menard, S., Chauvin, P., Mohamed, H.S., Charpentier, E., Mohamed, M.A., Berry, A. and Aboubaker, M.H., 2020. Misdiagnosis of imported falciparum malaria from African areas due to an increased prevalence of pfhrp2/pfhrp3 gene deletion: the Djibouti case. Emerg. microbes \& infect., 9(1), pp.1984-1987.

14. Ismail, I.M., Kahar, A., Sai, B., Samanth, B.M., Kumar, M.A. and Vishnu, R., 2019. Clinical profile and geographical distribution of malaria patients attending a tertiary care centre in Mangaluru, South India.

15. Kho, W.G., Chung, J.Y., Sim, E.J., Kim, M.Y., Kim, D.W., Jongwutiwes, S. and Tanabe, K., 2003. A multiplex polymerase chain reaction for a differential diagnosis of Plasmodium falciparum and Plasmodium vivax. Parasitol. Int., 52(3), pp.229-236.

16. Kozicki, M., Czepiel, J., Biesiada, G., Nowak, P., Garlicki, A. and Wesełucha-Birczyńska, A., 2015. The ring-stage of Plasmodium falciparum observed in RBCs of hospitalized malaria patients. Analyst, 140(23), pp.8007-8016.

17. Krishna, S., Bharti, P.K., Chandel, H.S., Ahmad, A., Kumar, R., Singh, P.P., Singh, M.P. and Singh, N., 2015.Detection of mixed infections with Plasmodium spp. by PCR, India, 2014. Emerg. Infect. Dis., 21(10), p.1853.

18. Kumar, N., Pande, V., Bhatt, R.M., Shah, N.K., Mishra, N., Srivastava, B., Valecha, N. and Anvikar, A.R., $2013 . \quad$ Genetic deletion of HRP2 and HRP3 in Indian Plasmodium falciparum population and false negative malaria rapid diagnostic test. Acta Trop, 125(1), pp.119-121

19. Limaye, C.S., Londhey, V.A. and Nabar, S.T., 2012. The study of complications of vivax malaria in comparison with falciparum malaria in Mumbai.J Assoc Physicians India,60, pp.15-18.

20. Makkar, R.P.S., Monga, S.M.A. and Gupta, A.K., 2002. Plasmodium vivax malaria presenting with severe thrombocytopenia. Braz J Infect Dis, 6, pp.263-265.

Page $15 / 22$ 
21. Maltha, J., Gamboa, D., Bendezu, J., Sanchez, L., Cnops, L., Gillet, P. and Jacobs, J., 2012. Rapid diagnostic tests for malaria diagnosis in the Peruvian Amazon: impact of pfhrp2 gene deletions and cross-reactions. PLOS ONE 7(8): e43094. https://doi.org/10.1371/journal.pone.0043094

22. Malaria, R.B. and World Health Organization, 2000. New perspectives: malaria diagnosis: report of a joint WHO (No. WHO/CDS/RBM/2000.14). World Health Organization.

23. Mehndiratta, S., Rajeshwari, K. and Dubey, A.P., 2013. Multiple-organ dysfunction in a case of Plasmodium vivax malaria. J. Vector Borne Dis, 50(1), p.71.

24. Meibalan, E. and Marti, M., 2017. Biology of malaria transmission. Cold Spring Harb. Perspect. Med, 7(3), p.a025452.

25. Menegon, M., L'Episcopia, M., Nurahmed, A.M., Talha, A.A., Nour, B.Y. and Severini, C., 2017. Identification of Plasmodium falciparum isolates lacking histidine-rich protein 2 and 3 in Eritrea. Infect. Genet. Evol.,55, pp.131-134.

26. Miguel-Oteo, M., Jiram, A.I., Ta-Tang, T.H., Lanza, M., Hisam, S. and Rubio, J.M., 2017. Nested multiplex PCR for identification and detection of human Plasmodium species including Plasmodium knowlesi. Asian

Pac. j. trop. med., 10(3), pp.299-304.

27. Nagata, N., Shimbo, T., Akiyama, J., Nakashima, R., Nishimura, S., Yada, T., Watanabe, K., Oka, S. and Uemura, N., 2012. Risk factors for intestinal invasive amebiasis in Japan, 2003-2009. Emerg. Infect. Dis., 18(5), p.717.

28. Nderu, D., Kimani, F., Thiong'o, K., Karanja, E., Akinyi, M., Too, E., Chege, W., Nambati, E., Meyer, C.G.andVelavan, T.P., 2019. Plasmodium falciparum histidine-rich protein (PfHRP2 and 3) diversity in Western and Coastal Kenya. Sci. Rep., 9(1), pp.1-9.

29. Okoth, S.A., Abdallah, J.F. and Solano, C.M., 2015. Deletion of Plasmodium falciparum Histidine-Rich Protein 2 (pfhrp2) and Histidine-Rich Protein 3 (pfhrp3) Genes in Colombian Parasites. PLoS One, 10(7), e0131576.

30. Other Tests [Internet]. Malaria Site. 2015 [cited 2021 Feb 21]. Available from: https://www.malariasite.com/other- tests/

31. Padley, D., Moody, A.H., Chiodini, P.L. and Saldanha, J., 2003. Use of a rapid, single-round, multiplex PCR to detect malarial parasites and identify the species present. Ann. trop. med. parasitol, 97(2), pp.131-137.

32. Pakalapati, D., Garg, S., Middha, S., Kochar, A., Subudhi, A.K., Arunachalam, B.P., Kochar, S.K., Saxena, V., Pareek, R.P., Acharya, J. and Kochar, D.K., 2013. Comparative evaluation of microscopy, OptiMAL ${ }^{\circledR}$ and 18SrRNA gene based multiplex PCR for detection of Plasmodium falciparum \& Plasmodium vivax from field isolates of Bikaner, India. Asian Pac. j. trop. med., 6(5), pp.346-351.

33. Pati, P., Dhangadamajhi, G., Bal, M. and Ranjit, M., 2018. High proportions of pfhrp2 gene deletion and performance of HRP2-based rapid diagnostic test in Plasmodium falciparum field isolates of Odisha. Malar. J.,17(1), pp.1-11.

34. Patsoula, E., Spanakos, G., Sofianatou, D., Parara, M. and Vakalis, N.C., 2003. A single-step, PCR-based method for the detection and differentiation of Plasmodium vivax and P. falciparum. Annals Ann. trop. med. parasitol, 97(1), pp.15-21.

35. Perandin, F., Manca, N., Calderaro, A., Piccolo, G., Galati, L., Ricci, L., Medici, M.C., Arcangeletti, M.C., Snounou, G., Dettori, G. and Chezzi, C., 2004. Development of a real-time PCR assay for detection of Plasmodium falciparum, Plasmodium vivax, and Plasmodium ovale for routine clinical diagnosis. J. Clin. Microbiol., 42(3), pp.1214-1219.

36. Pinheirob, V.E., Thaithongc, S. and Browna, K.N., 1993. High sensitivity of detection of human malaria parasites by the use of nested polymerase chain reaction. Mol. Biochem. Parasitol, 61, pp.315-320.

37. Rachid Viana, G.M., AkinyiOkoth, S., Silva-Flannery, L., Lima Barbosa, D.R., Macedo de Oliveira, A., Goldman, I.F., Morton, L.C., Huber, C., Anez, A., Dantas Machado, R.L. and Aranha Camargo, L.M., 2017. Histidine-rich protein 2 (pfhrp2) and pfhrp3 gene deletions in Plasmodium falciparum isolates from select sites in Brazil and Bolivia. PLoS One, 12(3), p.e0171150.

38. Roberts $\mathrm{CH}$, Armstrong M, Zatyka E, Boadi S, Warren S, Chiodini PL, Sutherland CJ, Doherty T. Gametocyte carriage in Plasmodium falciparum-infected travellers. Malar. J.2013 Dec,12(1):1-6.

39. Rougemont, M., Van Saanen, M., Sahli, R., Hinrikson, H.P., Bille, J. and Jaton, K., 2004. Detection of four Plasmodium species in blood from humans by $18 \mathrm{~S}$ rRNA gene subunit-based and species-specific real-time PCR 
assays. J. Clin. Microbiol., 42(12), pp.5636-5643.

40. Rubio, J.M., Benito, A., Roche, J., Berzosa, P.J., Garcia, M.L., Mico, M., Edu, M. and Alvar, J., 1999. Semi-nested, multiplex polymerase chain reaction for detection of human malaria parasites and evidence of Plasmodium vivax infection in Equatorial Guinea. Am. J. Trop. Med. 60(2), pp.183-187.

41. Rubio, J.M., Post, R.J., van Leeuwen, W.D., Henry, M.C., Lindergard, G. and Hommel, M., 2002. Alternative polymerase chain reaction method to identify Plasmodium species in human blood samples: the semi-nested multiplex malaria PCR (SnM-PCR). Trans. R. Soc., 96, pp.S199-S204.

42. Singh, B., Bobogare, A., Cox-Singh, J., Snounou, G., Abdullah, M.S. and Rahman, H.A., 1999. A genus-and speciesspecific nested polymerase chain reaction malaria detection assay for epidemiologic studies. Am J Trop Med Hyg.,1999 Apr,60(4):687-92

43. Singh, V., Mishra, N., Awasthi, G., Dash, A.P. and Das, A., 2009. Why is it important to study malaria epidemiology in India?. Trends Parasitol., 25(10), pp.452-457.

44. Siwal, N., Singh, U.S., Dash, M., Kar, S., Rani, S., Rawal, C., Singh, R., Anvikar, A.R., Pande, V. and Das, A., 2018. Malaria diagnosis by PCR revealed differential distribution of mono and mixed species infections by Plasmodium falciparum and P. vivax in India. PLoS One.,13(3), p.e0193046.

45. Trampuz, A., Jereb, M., Muzlovic, I. and Prabhu, R.M., 2003. Clinical review: Severe malaria. J. Crit. Care., 7(4),pp.1-9.

46. World Health Organization, 2015. Global technical strategy for malaria 2016-2030. World Health Organization.

47. World Health Organization, 2019. The "World malaria report 2019" at a glance. World Health Organization,Geneva, Switzerland.

48. World Health Organization. Global Malaria Programme-GMP. WHO Malaria Threats Map (https://www.who.int/malaria/maps/threats/),

\section{Figures}




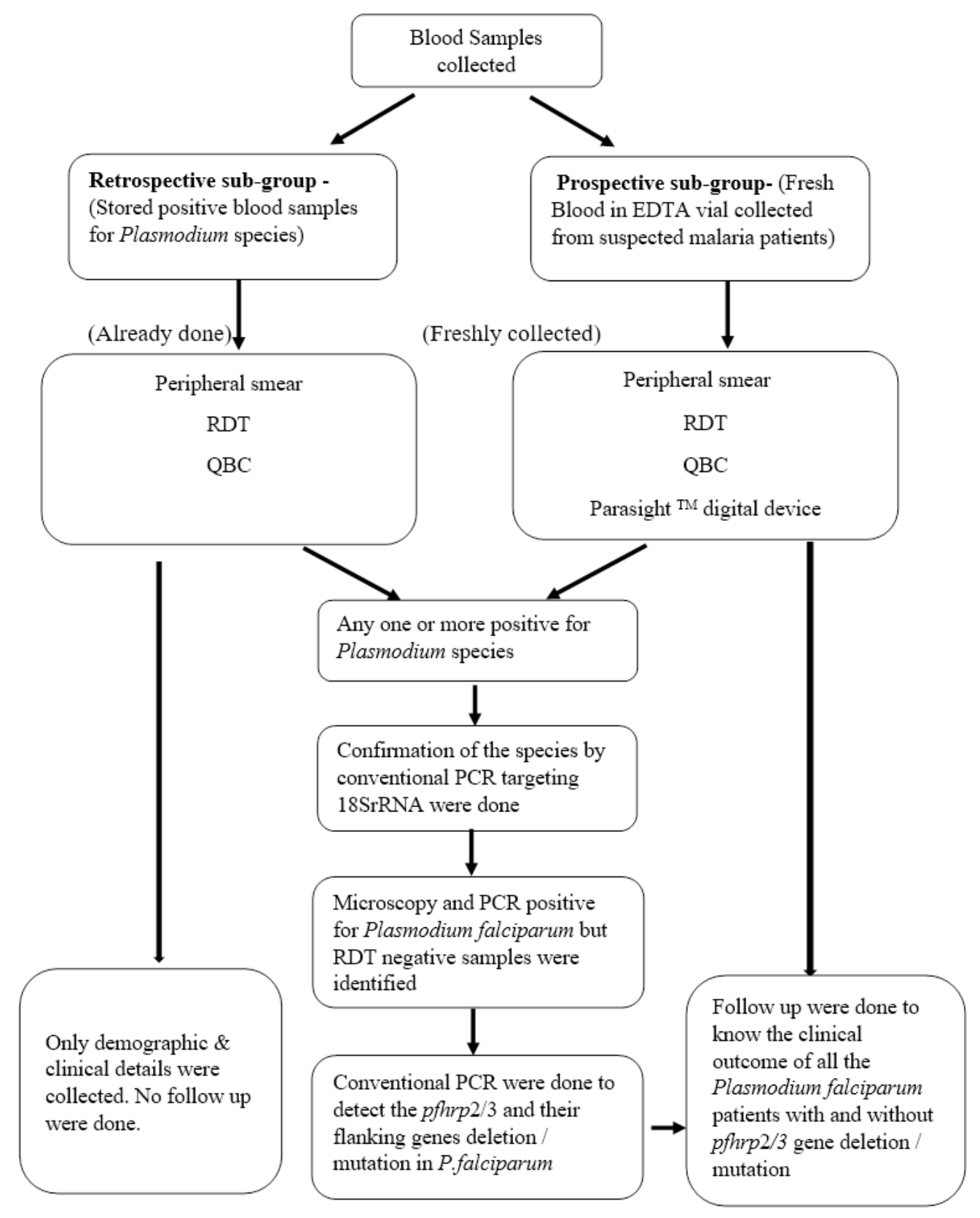

Figure 1

WORK FLOW chart 


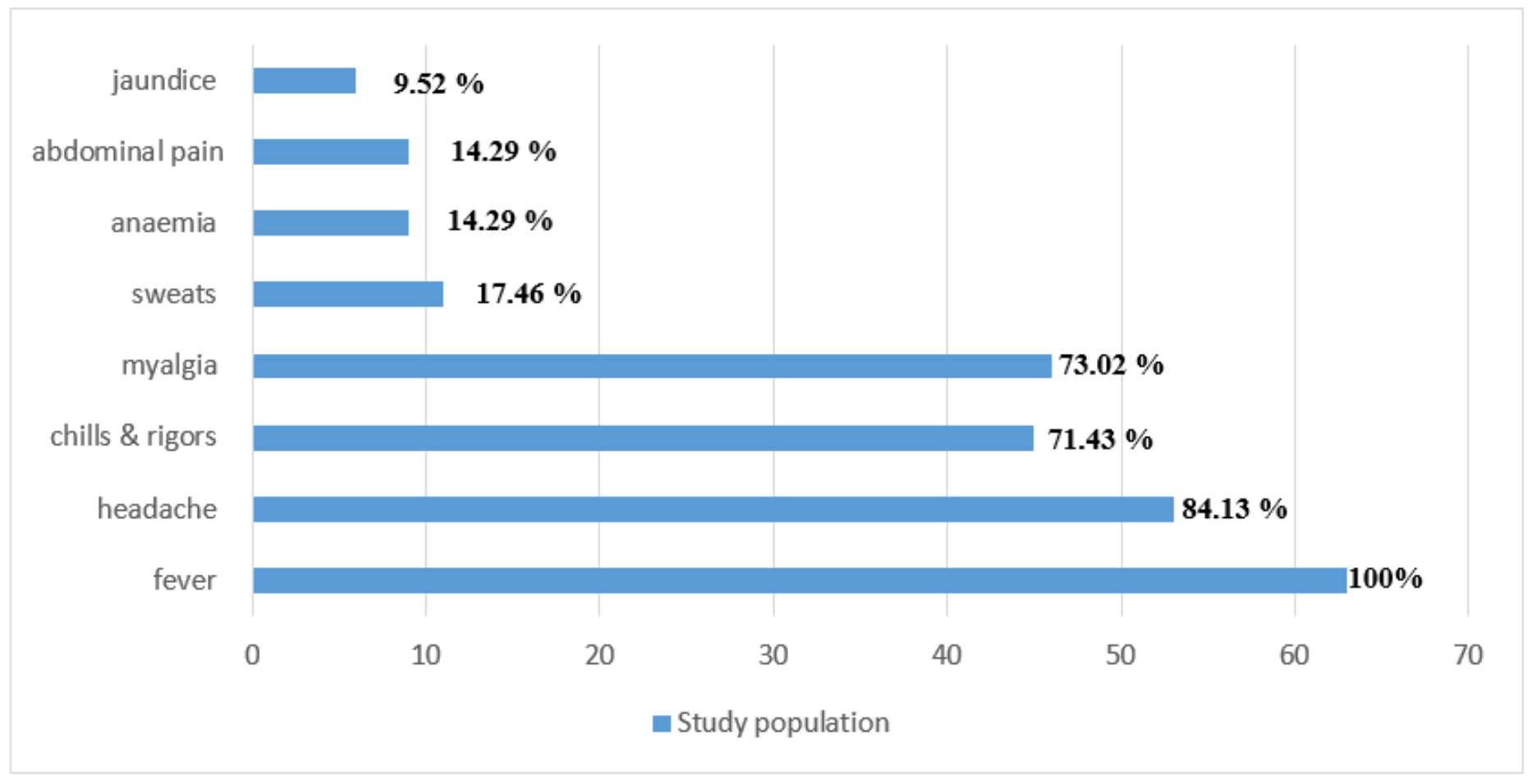

\section{Figure 2}

Various clinical manifestations of malaria in the study population (Clinical features in $\mathrm{Y}$ axis and number of patients in $\mathrm{X}$ axis)

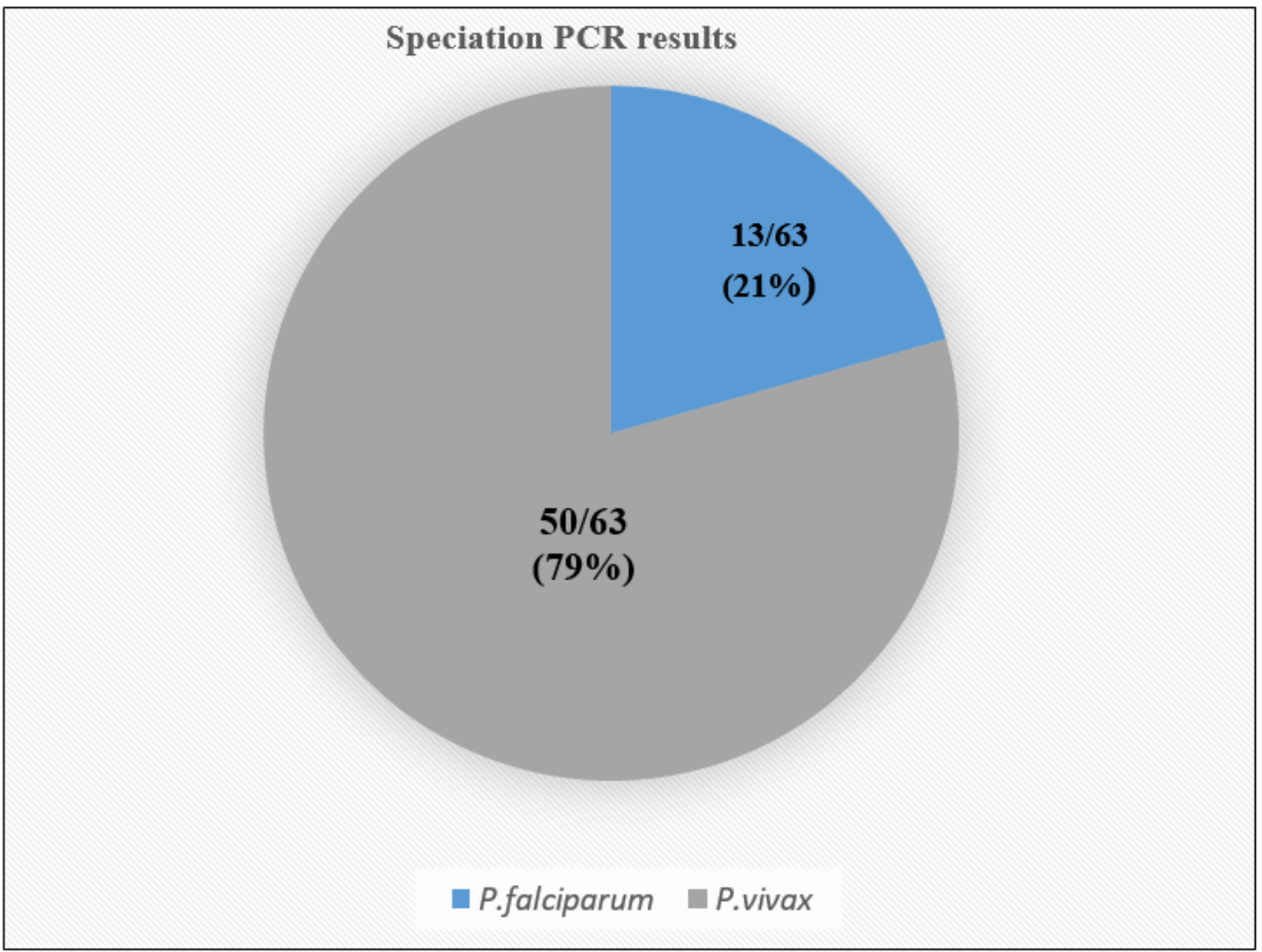


Figure 3

Plasmodium Speciation PCR results

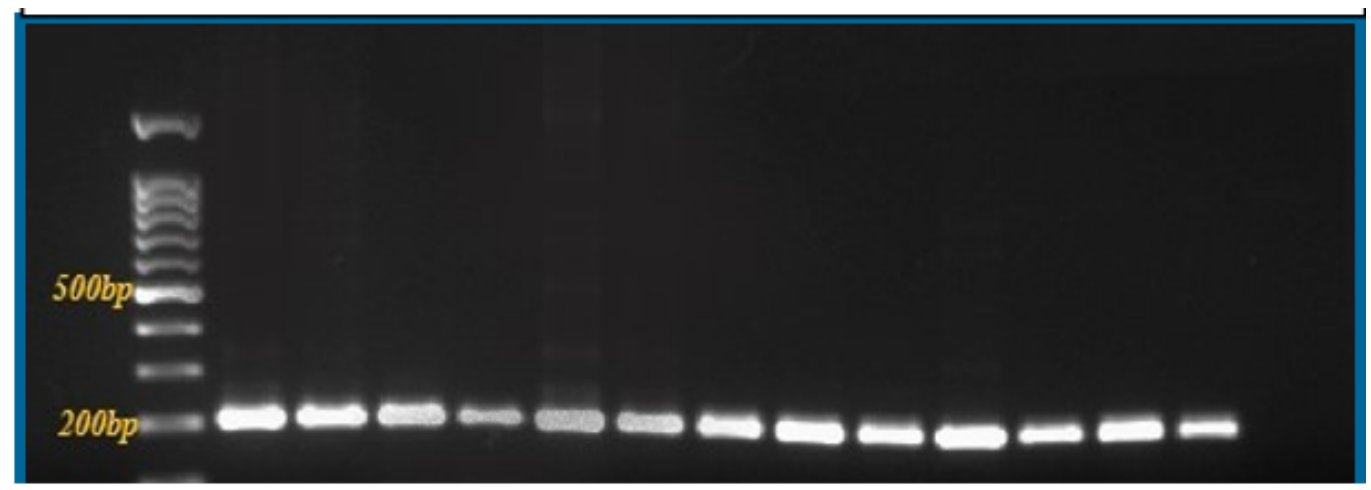

Figure 4

Speciation PCR - Plasmodium falciparum

Lane 1 - 100bpDNA ladder

Lane 2 - Pfalciparum PC

Lane 3 to 14 -Test samples

Lane 15 - NC

Figure 5

Speciation PCR - Plasmodium vivax

Lane 1-100bpDNA ladder

Lane 2 -P.vivax PC

Lane 3 to 12 -Test samples

Lane 13 - NC 


\section{pfhrp3 -2}

Figure 6

Pfhrp2-2 and Pfhrp3-2 PCR

Lane 1\& 8- 100 bp DNA ladder,

Lane 2\&9- pfhrp 2\&3 PC;

Lane 3-6 \&Lane 10-13 - Test

Lane 7 \&14 - NC

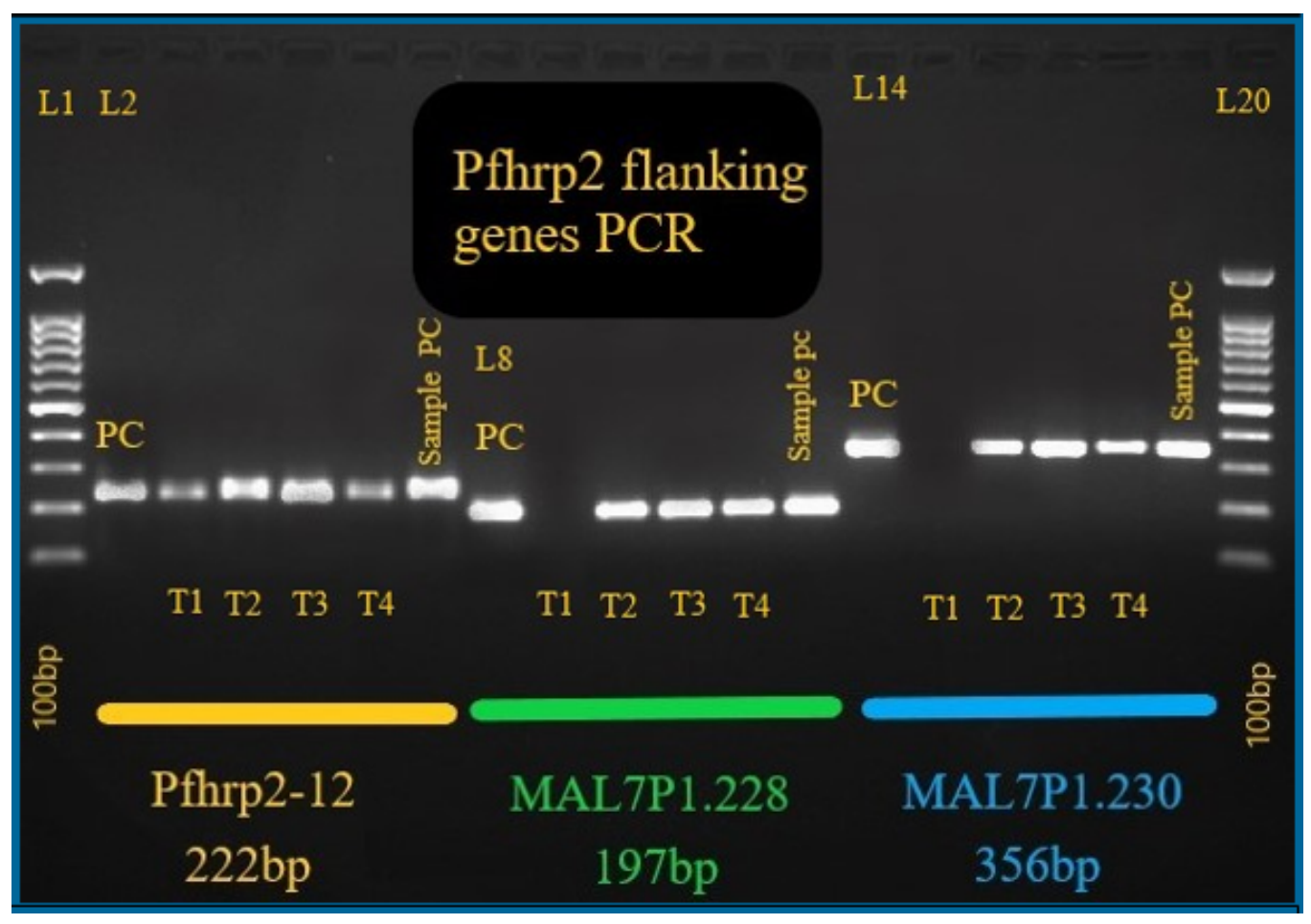


Figure 7

\section{Pfhrp2 flanking gene PCR}

Lane 1\& 20- 100 bp DNA ladder;

Lane 2, 8, 14- pfhrp2 flanking gene PC;

T1-T4 -Test samples

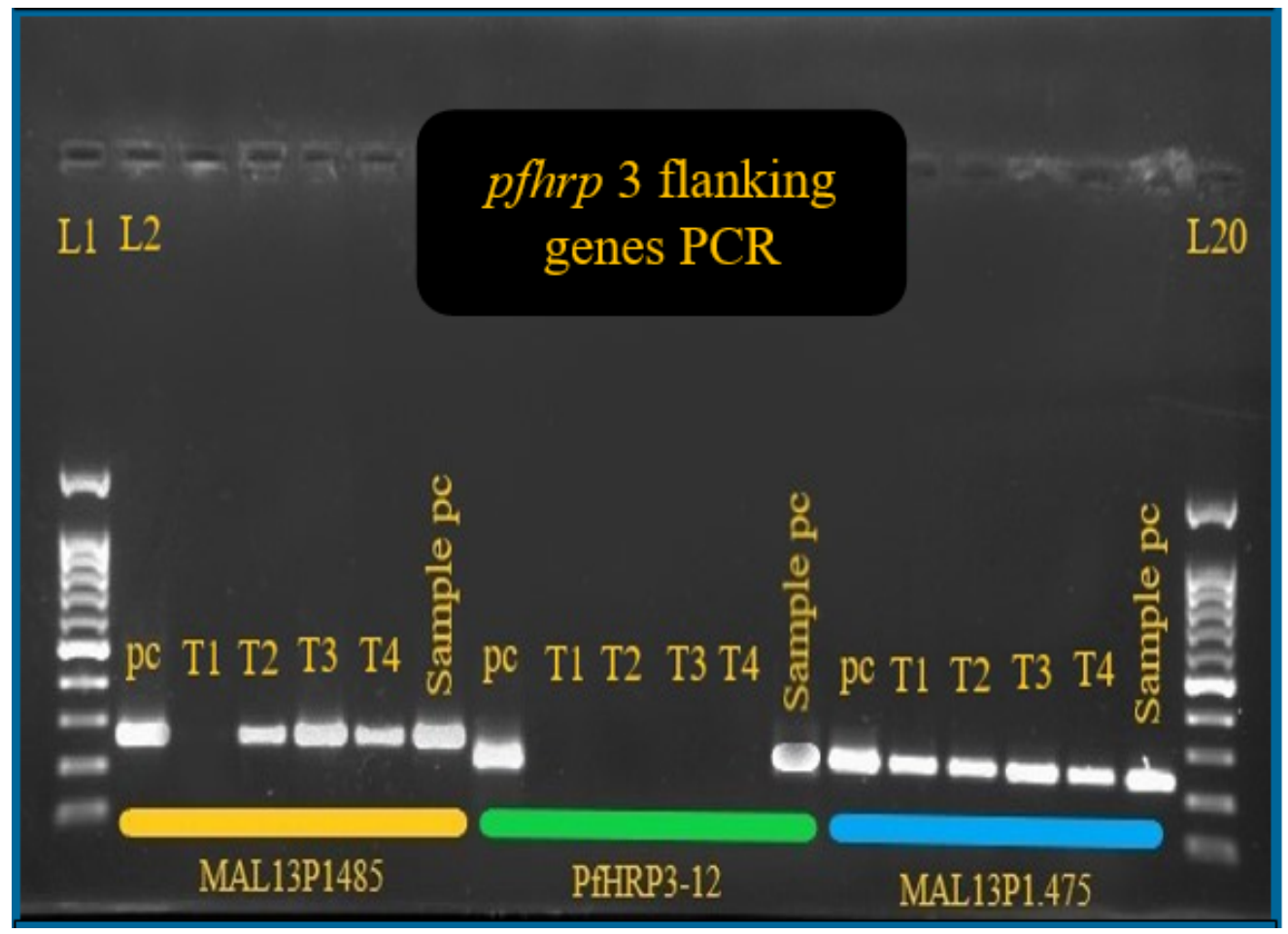

Figure 8

Pfhrp 3 flanking gene PCR

Lane 1\& 20- 100 bp DNA ladder;

Lane 2, 8, 14- pfhrp3 flanking gene PC;

T1-T4 -Test samples 